\title{
Upaya dan Tindakan Strategis dalam Peningkatan Pelaksanaan Penyuluhan Pertanian Kecamatan Balongpanggang Kabupaten Gresik
}

\author{
Resya Nurdyawati ${ }^{1{ }^{*}}$, Dinda Purwati ${ }^{2)}$ \\ 1)*Dosen Program Studi Agribisnis, Fakultas Pertanian Universitas Muhammadiyah \\ Gresik \\ ${ }^{2)}$ Mahasiswa Program Studi Agribisnis, Fakultas Pertanian Universitas Muhammadiyah \\ Gresik \\ E-mail: resyanurdyawati@umg.ac.id ${ }^{1{ }^{*}}$, dindapurwati.03@gmail.com ${ }^{2)}$
}

\begin{abstract}
ABSTRAK
Penyuluhan pertanian sangat berperan penting sebagai wadah petani untuk belajar secara terus menerus. Selama ini penyelenggaraan penyuluhan masih fokus kepada efektivitas misalnya diukur dengan produktivitas pertanian namun kurang memperhatikan keberlanjutan. Penelitian ini bertujuan untuk mengkaji bagaimana upaya dan tindakan strategis dalam peningkatan pelaksanaan penyuluhan pertanian di Kecamatan Balongpanggang Kabupaten Gresik. Metode yang digunakan dalam penelitian ini adalah sensus kepada tujuh orang penyuluh dan 4 orang ketua gapoktan yang dipilih secara sengaja. Metode analisis menggunakan analisis deskriptif. Hasil penelitian menunjukkan diperlukannya upaya dan tindakan strategis untuk meningkatkan pelaksanaan penyuluhan pertanian melalui stakeholder yang terlibat, yaitu pemerintah, penyuluh, dan petani secara Bersama-sama.
\end{abstract}

Kata kunci : Upaya, Tindakan, Penyuluhan

\section{Pendahuluan}

Peran pertanian dinilai sangat besar untuk suatu negara, yaitu sebagai penyedia bahan pangan serta bahan baku industri. Dengan peran yang besar tersebut menjadikan sektor pertanian sebagai sektor vital bagi suatu negara. Peningkatan devisa juga dapat dilaksanakan oleh sektor pertanian melalui kegiatan ekspor produk pertanian. Selain itu, dengan adanya ekspor produk pertanian, pertumbuhan ekonomi Indonesia dapat ditumbuhkan dan tenaga kerja dapat terserap (Satriana, et al., 2019). Oleh karena itu diperlukan suatu cara guna meningkatkan pelaksanaan penyuluhan pertanian.

Peningkatan pelaksanaan penyuluhan pertanian yang lebih efektif dan efisien dapat dibangun melalui pemahaman terhadapfalsafah penyuluhan. Suhardiyono (1990) menyebutkan bahwa falsafah penyuluhan tersusun atas tiga landasan dasar dalam bekerja yang berupa proses pendidikan, proses demokrasi serta proses yang berlangsung secara kontinu. Oleh karena itu, kegiatan penyuluhan adalah kegiatan belajar yang 
berlangsung secara kontinu, sehingga menciptakan adanya perubahan pada diri seseorang atau kelompok masyarakat tanpa adanya paksaan terhadap masyarakat sasaran (petani). Pada kegiatan penyuluhan juga perlu diperhatikan pula tentang prinsip penyuluhan yang nantinya akan berguna sebagai pegangan kerja pada pelaksanaan kegiatan penyuluhan, ataupun dapat juga digunakan sebagai pemberi arah pada proses pemecahan masalah sehingga masalah yang dihadapi petani dapat terpecahkan secara efektif. Valera, et al. (dalam Syabrina, 2009) menyebutkan bahwa prinsip penyuluhan merupakan : (1) kegiatan penyuluhan yang dilakukan secara bersama-sama dengan klien atau sasaran, sehingga kegiatan penyuluhan tidak hanya dilakukan untuk klien/sasaran, (2) kegiatan penyuluhan dilakukan secara bekerjasama serta dengan berkoordinasi bersama organisasi pembangunan lain, (3) kegiatan penyuluhan merupakan kegiatan bertukar informasi secara dua arah antara klien/sasaran dengan penyuluh, (4) kegiatan penyuluhan dilakukan secara berkelompok dengan kelompok tani sasaran, serta (5) dalam kegiatan penyuluhan diperlukan partisipasi aktif pada masyarakat untuk turut terlibat pada setiap kegiatan belajar pada penyuluhan.

Selama ini penyelenggaraan penyuluhan masih fokus kepada efektivitas misalnya diukur dengan produktivitas pertanian namun kurang memperhatikan keberlanjutan. Strategi dan instrumen kebijakan sangat diperlukan lantaran dapat memengaruhi perubahan perilaku yaitu dengan memodifikasi penerapan perilaku tertentu, menerapkan regulasi, memberikan insentif ekonomi, memberikan informasi, pendidikan dan komunikasi dan terakhir dengan cara wait and see menggunakan skenario tertentu (Boersema dan Reijnders 2009). Peran tersebut dapat dilaksanakan oleh para penyuluh sebagai agen perubahan untuk mempercepat difusi inovasi melalui pendidikan non-formal. Porter (1996) mengungkapkan bahwa efektivitas operasional suatu kegiatan bukanlah suatu strategi. Oleh karena itu, kajian ini diperlukan untuk melihat bagaimana upaya dan tindakan strategis dalam peningkatan pelaksanaan penyuluhan pertanian di Kecamatan Balong panggang Kabupaten Gresik.

\section{Metode}

Data pada penelitian ini diperoleh melalui kegiatan observasi langsung, wawancara mendalam kepada tujuh penyuluh Balai Penyuluhan Pertanian Balongpanggang yang dipilih secara sensus. Responden lain yang diambil adalah dari segi penerima penyuluhan yaitu petani yang dipilih secara sengaja yaitu 4 orang ketua gapoktan yang dapat merepresentasikan petani secara umum di wilayah kerja BPP Balongpanggang. Pemilihan lokasi penyuluhan BPP Balongpanggang dilandasi atas dasar bahwa kecamatan Balongpanggang merupakan cakupan wilayah Gresik bagian tengah dengan potensi wilayah pertanian dengan jumlah produksi padi tertinggi di Kabupaten Gresik, hal ini karena luas panen padi di Kecamatan Balongpanggang merupakan yang terluas jika dibandingkan dengan wilayah kecamatan lainnya yang ada di Kabupaten Gresik bagian tengah ataupun Kabupaten Gresik secara keseluruhan. 


\begin{abstract}
Analisis deskriptif digunakan untuk menginterpretasikan sifat beberapa fenomena kelompok berdasarkan fakta yang ada. Sugiyono (2004) menyebutkan bahwa analisis deskriptif merupakan statistik analisis data yang memberikan penjelasan tanpa membuat generalisasi atau kesimpulan umum. Dalam penelitian ini digunakan untuk menggambarkan upaya dan tindakan yang dapat dilakukan guna meningkatkan Pelaksanaan penyuluhan pertanian di Kecamatan Balongpanggang.
\end{abstract}

\section{Hasil dan Pembahasan}

Upaya dan tindakan strategis untuk meningkatkan pelaksanaan penyuluhan di Kecamatan Balongpanggang dapat dilakukan oleh stakeholder pertanian mulai dari pemerintah yang dalam hal ini adalah dinas pertanian, penyuluh dan petani.

\section{Dinas Pertanian}

Pelaksanaan penyuluhan pertanian di kecamatan Balongpanggang terkendala pada ketersedian jumlah personil penyuluh. Berdasarkan UU No. 19 tahun 2013 disebutkan bahwa ketersediaan jumlah penyuluh adalah satu penyuluh dalam satu desa. kecamatan Balongpanggang terdiri dari 25 desa dengan jumlah penyuluh sebanyak 7 orang, sehingga beban kerja penyuluh lebih besar dan hal tersebut dapat mempengaruhi kinerja penyuluh pertanian. Selain terkait jumlah penyuluh, kendala yang dialami oleh BPP Balongpanggang adalah kurang tersedianya sarana dan prasarana penyuluhan. Tidak adanya media LCD yang dapat digunakan oleh penyuluh dalm melakukan penyuluhan. Bantuan LCD diharapkan oleh penyuluh agar penyebaran materi pada saat penyuluhan secara kelompok lebih menarik minat petani untuk berpartisipasi dalam kegiatan penyuluhan. Maka dari itu, berdasarkan masalah dan kendala yang ada, maka upaya dan tindakan yang dapat dilakukan oleh pemerintah khususnya dinas pertanian guna meningkatkan efektivitas penyuluhan adalah dengan meningkatkan anggaran untuk sektor pertanian serta melakukan rekrutmen dalam menambah jumlah penyuluh pertanian. Hal ini sesuai dengan pendapat Mayrowani (2012) yang menyatakan bahwa pemerintah harus memberikan perhatian dalam pengembangan kelembagaan pembiayaan dan kelembagaan usaha kelompok berbadan hukum.

Pelaksanaan kegiatan penyuluhan pada era otonomi daerah atau yang dikenal sebagai desentralisasi menyebabkan adanya perbedaan pemberian wewenang serta tanggung jawab antara kabupaten atau kota dengan pemerintah pusat baik secara langsung atau melalui pemerintah provinsi dalam hal penyelenggaraan penyuluhan. Pemerintah kabupaten atau kota bertanggung jawab pada merencanakan kegiatan penyuluhan, kelembagaan penyuluhan, kebutuhan jumlah tenaga penyuluh, program penyuluhan, manajemen penyuluhan, serta dalam hal yang berkaitan dengan anggaran penyuluhan. Pemerintah provinsi yang mendapat mandat dari pemerintah pusat ataupun pemerintah pusat secara langsung bertanggung jawab dalam hal memberikan fasilitas kepada pemerintah kabupaten atau kota agar bisa melaksanakan kegiatan penyuluhan secara efektif dan efisien serta produktif berdasarkan kebutuhan lokalita (Badan Pengembangan SDM Pertanian, 2003). 


\section{Penyuluh}

Peranan kelembagaan penyuluhan berperan dalam penentuan efektivitas kelompok tani yang secara langsung berguna sebagai wadah pada kegiatan pendidikan, unit produksi, serta wadah untuk bekerja, sehingga saat kelembagaan kelompok tani dapat terselenggara dengan baik serta dapat berjalan secara mandiri, maka kelompok tani dapat berubah fungsi menjadi kelompok usaha. Penyuluh pertanian adalah ujung tombak dalam pembangunan pertanian, maka penyuluh harus terus meningkatkan kinerjanya. Penyuluh harus lebih giat lagi dalam menyebarkan informasi ditingkat petani baik secara kelompok/massal maupun secara individu. Penyuluh juga lebih progresif dalam pencapaian target produksi dan produktivitas komoditas pertanian dan perbaikan sikap yang dapat dibangun melalui proses pembinaan, pengawasan serta evaluasi, sehingga penyuluh dapat melakukan kegiatan penyuluhan pertanian secara intensif kepada petani sebagai pelaku utama maupun kepada pelaku usaha (Afrinawati et al., 2016).

Dengan memasuki era industri 4.0 maka penyuluh juga diharapkan dapat berinovasi dalam penyuluhan yaitu dengan melakukan penyuluhan melalui media sosial dan elektronik sehingga dapat menarik minat pemuda untuk terjun dibidang pertanian. Oleh karea itu, untuk menarik minat pemuda agar dapat terjun di sektor pertanian, seorang penyuluh harus dapat mengemas program penyuluhan agar sesuai dengan kearifan lokal masyarakat setempat serta searah dengan potensi daerah yang ada. Program penyuluhan yang sesuai dengan market demand juga harus dimunculkan pada program penyuluhan agar dapat terpenuhinya semua kebutuhan masyarakat (Rahmawati et al., 2019).

\section{Petani}

Masalah ditingkat petani kecamatan Balongpanggang adalah kurangnya penerapan pertanian organik seperti yang telah disaranakan oleh penyuluh. Selain itu berdasarkan programa penyuluhan pertanian Kecamatan Balongpanggang disebutkan bahwa dalam penyusunan programa penyuluhan pertanian masih di dominasi oleh penyuluh/petugas (petani kurang partisipasif). Padahal seharusnya dalam penyusunan programa penyuluhan juga diperlukan keterlibatan secara aktif dari petani.

Maka, upaya dan tidakan yang dapat dilakukan petani adalah petani yang belum menerapkan pertanian organik dapat melakukan penerapan pertanian organik seperti yang telah disarankan karena penerapan organik dapat membantu memperbaiki struktur tanah. Selain itu petani dapat berpastisipasi secara penuh dalam kegiatan penyusunan programa serta dalam kegiatan penyuluhan walaupun tidak ada formulator.

\section{Kesimpulan}

Penyuluhan pertanian penting dilakukan untuk menggerakkan petani dalam kegiatan berusahatani. Oleh karenanya diperlukan upaya dan tindakan strategis untuk meningkatkan pelaksanaan penyuluhan pertanian melalui stakeholder yang terlibat, yaitu pemerintah yang dalam hal ini adalah Dinas Pertanian dengan memberikan perhatian lebih terhadap ketersedian sarana prasarana kegiatan penyuluhan. Penyuluh pertanian sebagai pelaku kegaiatan penyuluhan dapat melalukan upaya-upaya yang inovatif agar dapat menarik petani untuk lebih aktif 
mengikuti kegiatan penyuluhan, serta petani sebagai sasaran penyuluhan diharapkan dapat mengikuti arahan yang disampaikan oleh penyuluh dan juga lebih berperan aktif dalam kegiatan penyuluhan yang dilaksanakan.

\section{Daftar Pustaka}

Afrinawati, Usman, M., dan Baihaqi, A., 2016. Efektivitas Penyuluhan Pertanian terhadap Pendapatan Usahatani Padi Sawah di Kecamatan Indrapuri Kabupaten Aceh Besar. Jurnal Ilmiah Mahasiswa Pertanian Unsyiah. 1(1): 299-304.

Badan Pengembangan SDM Pertanian. 2003. Nasional Pengembangan Penyuluh Pertanian. Departemen Pertanian: Jakarta.

Boersema, J. J., dan Reijnders, L. 2009. Principles of Environmental Sciences. Springer Science Business Media: United Kingdom.

Mayrowani, H. 2012. Pembangunan Pertanian pada Era Otonomi Daerah: Kebijakan dan Implementasi. FORUM PENELITIAN AGRO EKONOMI, Vol. 30, No. 1.
Porter, M.E. 1996. Strategi Bersaing: Teknik Menganalisis Industri dan Pesaing. Erlangga: Jakarta.

Rahmawati, Baruwadi, M., dan Bahua, M.I. 2019. Peran Kinerja Penyuluh dan Efektivitas Pelaksanaan Penyuluhan pada Program Intensifikasi Jagung. Jurnal Sosial Ekonomi Pertanian, Vol. 15, No. 1.

Satriana, E.D., Harianto, dan Dominicus, S.P. 2019. Pengaruh Volatilitas Nilai Tukar terhadap Kinerja Ekspor Utama Pertanian Indonesia. Buletin Ilmiah Litbang Perdagangan, Vol. 13, No. 2.

Sugiyono. 2004. Metode Penelitian dan Pengembangan. Alfabet : Bandung.

Suhardiyono, L. 1990. Penyuluhan : Petunjuk bagi Penyuluhan Pertanian. Erlangga: Jakarta.

Syabrina, E. 2009. Analisis Kelembagaan Penyuluhan Pertanian di Provinsi Riau [Tesis].

Undang-Undang Nomor 19 tahun 2013. 